http://dx.doi.org/10.12775/szhf.2016.032

\author{
Milena Kulasek
}

Uniwersytet MikoŁaja Kopernika, Toruń, Polska

milena.kulasek@gmail.com

\title{
Genetyka człowieczeństwa. Krytyka argumentu z ciągłości genetycznej
}

\section{Wstęp}

Zarówno ciało embrionu, które było moim ciałem przed laty, jak i moje obecne i przyszłe ciało mają tę samą kombinację genów. Jednak czy ta ciągłość genetyczna warunkuje ciągłość mojej osoby? W dzisiejszej kulturze zawarty w komórkach kwas deoksyrybonukleinowy (DNA) wydaje się symbolem indywidualności i tożsamości, a czasami jest wręcz uważany za istotę człowieka. Geny, w które jest brzemienne DNA, są postrzegane przez wielu naukowców: „nie tylko jako potężna biologiczna jednostka, ale także jako święty tekst, który może wyjaśnić naturalny i moralny porządek"1.

$\mathrm{W}$ momencie zapłodnienia powstaje nowy garnitur chromosomowy, który trudno nazwać prostą sumą materiału niesionego przez wyjściową komórkę jajową i plemnik. Geny matczyne i ojcowskie współdziałają ze sobą, wpływają na siebie wzajemnie, uzupełniają, tworząc nową całość - nowy zestaw genów,

${ }^{1}$ D. Nelkin, S. Lindee, The DNA Mystique: the Gene as a Cultural Icon; cyt. za: M. A. Warren, The moral status of the gene, [w:] A Companion to Genetics, red. J. Burley, J. Harris, Blackwell Publishing Ltd 2004, s. 152. 
który w dalszym kształtowaniu istoty ludzkiej będzie kierował jej rozwojem. Według zwolenników tej cenzury człowieczeństwa „wszystko, co nastąpi później, jest konsekwencją tego pierwszego wydarzenia"2. Jest to istotna zmiana jakościowa w organicznej ciągłości, jaką wyznacza prawo omnis cellula e cellula (każda komórka [pochodzi] od [innej] komórki).

Jak zauważa Zbigniew Szawarski, argument z ciągłości genetycznej ma wiele wspólnego z traducjanizmem, starożytną doktryną mówiącą o tym, że Bóg bezpośrednio nie stwarza duszy ludzkiej, ale że dusza powstaje z ciałem $\mathrm{w}$ momencie poczęcia ${ }^{3}$. Można to interpretować w ten sposób, że w chwili zapłodnienia, gdy ustala się genom nowej istoty ludzkiej, materia ulega swego rodzaju rozdwojeniu - zapłodnieniu towarzyszy powstanie nowej, duchowej, rzeczywistości. Zygota jest pewnego rodzaju biologicznym oknem, przez które do świata przenika nowa, jednostkowa rzeczywistość.

\section{Problem bliźniąt jednojajowych}

Głównym powodem traktowania każdego człowieka w wyjątkowy sposób jest przypisywanie przynależności gatunkowej moralnego znaczenia ${ }^{4}$. Człowiek jako gatunek ma swoją tożsamość genetyczną, a analizując samo DNA, można określić przynależność danego organizmu do Homo sapiens. Podobnie jest na poziomie osobniczym. Zestaw genów, powstały w wyniku rozmnażania seksualnego, jest unikalny ${ }^{5}$ i pozwala odróżnić jeden organizm od drugiego za pomocą prostych testów genetycznych. Genetyczna tożsamość osobnika nie pokrywa się jednak z tożsamością osobową, na co wskazuje istnienie bliźniąt jednojajowych. Są one odrębnymi osobnikami, choć ich geny są identyczne. T. J. O’Donnell nie ma zatem racji, gdy postrzega: „chromosomalne struktury jąder w najwcześniejszych fazach podziału komórki jako swoiście ludzkie i naprawdę zindywidualizowane osobowo"6. To według wie-

\footnotetext{
${ }^{2}$ W. Bołoz, Bioetyka i prawa człowieka, Wydawnictwo Uniwersytetu Kardynała Wyszyńskiego, Warszawa 2007, s. 236.

${ }^{3}$ Z. Szawarski, Etyka i przerywanie ciąży, [w:] W kręgu życia i śmierci. Moralne problemy medycyny współczesnej, red. Z. Szawarski, Książka i Wiedza, Warszawa 1987, s. 169-201.

${ }^{4}$ Tamże, s. 173.

5 „Pseudozygota” powstała w wyniku klonowania za pomocą techniki transferu jądra komórkowego będzie miała jądrowy materiał genetyczny identyczny $z$ dawcą jądra.

${ }^{6}$ Z. Szawarski, Etyka i przerywanie ciąży..., s. 171.
} 
lu badaczy wystarczy, by wykluczyć indywidualność wczesnego embrionu: „fakt powstania identycznego bliźniactwa zakładałby podział już istniejącej jednostki ludzkiej jako całości na dwie nowe jednostki. To zaś wydaje się niemożliwe” ${ }^{\mathrm{i}}$ „kłóci się z zasadą niepodzielności bytów i zasadą indywidualizacji życia człowieka" ${ }^{8}$. Paradoksalność tych zdarzeń dobrze ujął Peter Singer:

Wyobraźmy sobie, że od momentu poczęcia embrion jest jednostką - nazwijmy ją Marion - a więc co stanie się z Marion, jeśli embrion się podzieli? Czy powstałe bliźnięta to Marion i nowe bliźnię, powiedzmy Ruth? Czy też będzie to dwoje zupełnie nowych bliźniąt, dajmy na to, Ruth i Esther? Każda odpowiedź prowadzi do paradoksów. Jeśli Marion nadal istnieje, to którym jest $\mathrm{z}$ bliźniąt? Nie mamy podstaw, by sądzić, że któreś $\mathrm{z}$ nich ma bliższy związek z pierwotną Marion. Lecz jeśli żadne z bliźniąt nie jest Marion, co się z nią stało? Czy zniknęła? Czy mamy boleć nad utratą jednostki ludzkiej, jak bolałbym nad zniknięciem jednej z moich córek, nawet gdyby na jej miejsce zjawiły się dwie nowe?"

Na tej podstawie odmawia się embrionowi przed 14 dniem ciąży statusu istoty niepodzielnej i jednostkowej ${ }^{10}$. Po tym czasie wykształca się struktura zwana smugą pierwotną, która jest oznaką początku gastrulacji. Wtedy wykształcają się trzy listki zarodkowe, których obecność świadczy o osiągnięciu stopnia specjalizacji, niepozwalającego na podział bliźniaczy.

\section{Genetyczny homunculus}

John Noonan utrzymuje, że „istota z ludzkim kodem genetycznym jest człowiekiem”"1. „Ludzki kod” rozumie on jako informację genetyczną, która

\footnotetext{
${ }^{7}$ N. M. Ford, Kiedy powstałem? Problem poczatku jednostki ludzkiej w historii $w$ filozofii i w nauce, przeł. W. J. Popowski, PWN, Warszawa 1995, s. 140.

${ }^{8}$ J. Sak, P. Kiciński, B. Kołodziejczyk, K. Marczewski, Bioetyczne aspekty ochrony życia człowieka w okresie prenatalnym, [w:] Etyka wobec sytuacji granicznych, red. D. Probucka, Oficyna Wydawnicza „Impuls”, Kraków 2007, s. 182.

${ }_{9}$ P. Singer, O życiu i śmierci. Upadek etyki tradycyjnej, przeł. A. Alichniewicz, A. Szczęsna, Państwowy Instytut Wydawniczy, Warszawa 1997, s. 107.

10 Tamże.

${ }^{11}$ J. Noonan, An almost absolute value in history, cyt. za: M. A. Warren, The moral status of the gene, [w:] A Companion to Genetics, eds. J. Burley, J. Harris, Blackwell Publishing 2004, s. 152 (przekł. autorki).
} 
decyduje o możliwości osiągnięcia przez człowieka mądrości. Trzydześci tysięcy genów, jakimi dysponuje każda istota ludzka, sprawia, że jest ona zdolna do rozwoju w samoświadomy, racjonalnie myślący organizm, który z kolei potrafi wytworzyć zaawansowaną technologię i kulturę. W tej perspektywie każda rozwinięta lub rozwijająca się istota o ludzkim genomie posiada równy status moralny, ponieważ istotnym składnikiem jej ciała jest DNA, składające się z „ludzkiej” sekwencji nukleotydów.

$\mathrm{Z}$ drugiej strony nie da się rozdzielić uwarunkowań genetycznych od uwarunkowań środowiskowych. Zapisane w DNA geny nie istnieją poza kontekstem komórkowym, bez niego są zwykłą substancją biochemiczną. Ich funkcjonowanie jest zależne od sieci powiązań przyczynowo-skutkowych z szeroko pojętym środowiskiem organizmu ${ }^{12}$. Nieznajomość tego faktu może prowadzić do redukcji człowieczeństwa do molekuły DNA, która niczym „genetyczny homunculus" kontroluje nasze życie w sposób ściśle deterministyczny. „Przeświadczenie, że wyłącznie geny determinują wszystkie aspekty osobnika jest nazywane "genetycznym determinizmem «. [...]. [jednak] jako istoty społeczne i biologiczne jesteśmy tworami naszego biologicznego, fizycznego, społecznego, politycznego, historycznego i psychologicznego środowiska" ${ }^{13}$. Geny nie są nośnikami pamięci, która determinuje ciągłość psychologiczną, a jedynie warunkują powstanie struktur mózgowych, pozwalających na wytwarzanie i magazynowanie wspomnień ${ }^{14}$. Ponadto poza ciałem matki zygota nie ma potencjału rozwojowego, by stać się nową, w pełni wykształconą istotą ludzką. Geny są jedynie jednym z wielu elementów biorących udział $\mathrm{w}$ tym skomplikowanym procesie ${ }^{15}$. Środowisko macicy i geny embrionu są partnerami w koordynowaniu rozwoju nowego człowieka ${ }^{16}$.

Mary Anne Warren atakuje argument wiążący posiadanie określonego materiału genetycznego z jakimikolwiek obowiązkami moralnymi, wskazując na to, że DNA jest jedynie częścią organizmu. Rozpoznanie tego faktu stanowi doskonały kontrargument dla argumentu z ciągłości genetycznej, jeśli uznamy dwie przesłanki. Po pierwsze, to całe organizmy działają teleologicznie, a DNA jedynie warunkuje określone funkcje osobnika, takie jak

\footnotetext{
${ }^{12}$ M. A. Warren, dz. cyt.

${ }^{13}$ National Bioethics Advisory Commission, Cloning Human Beings, cyt. za: B. Steinbock, Preimplantation Genetic Diagnosis and Embryo Selection, [w:] A Companion to Genetics, s. 184.

${ }^{14}$ C. Rovane, Genetics and Personal Identity, [w:] A Companion to Genetics, s. 247-248.

${ }^{15}$ M. A. Warren, dz. cyt.

${ }^{16}$ W. J. FitzPatrick, Totipotency and the Moral Status of Embryos: New Problems for an old Argument, Journal of Social Philosophy" 2004, vol. 35, no. 1, s. 112.
} 
rozmnażanie czy rozwój. Po drugie, o takich cechach jak świadomość czy działanie intencjonalne stwierdza się wobec całego organizmu, a nie jego części. Nie ma świadomego mózgu, ale jest świadomy organizm, nie ma intencjonalnie działającej ręki, ale intencjonalnie działający organizm. Tak samo nie ma świadomego ani intencjonalnego DNA. Dlatego absurdem jest traktować DNA jako podmiot obowiązków moralnych, skoro nie mamy ich wobec amputowanej ręki czy komórek skóry. Jak się wydaje, podejście do DNA jako czegoś, co powinno podlegać obowiązkom moralnym, wynika z silnego przekonania o całkowitym determinizmie genetycznym, co skłania do nadania dużego znaczenia moralnego "genetycznemu homunculusowi” ${ }^{17}$.

\section{Pozór ostrości i jednoznaczności}

Jedną z największych zalet, jakie przypisuje się kryterium poczęcia, jest jego niska problematyczność. Mamy oto zdarzenie, które charakteryzuje się widocznymi „gołym okiem” zmianami jakościowymi: liczba chromosomów podwaja się ${ }^{18}$, komórka przygotowuje się do podziału, aby stworzyć wielokomórkowy organizm o odmiennym genotypie niż rodzice, co nie pozwala traktować jej jak prostej sumy komórek rozrodczych.

Jak zauważają Peter Singer ${ }^{19}$ i Zbigniew Szawarski ${ }^{20}$, bliższe przyjrzenie się zapłodnieniu ujawnia fakt, że nie jest ono momentem, ale procesem, który trwa w czasie (około 24 godzin). Obejmuje całą sekwencję istotnych zdarzeń, takich jak: przenikanie plemnika przez osłonkę przejrzystą, utratę przez niego wici, fuzję błon komórkowych obu gamet, rozpoczęcie wędrówki przedjądrza męskiego do przedjądrza żeńskiego, „całowanie się” przedjądrzy, ich fuzję, przygotowanie do podziału komórkowego. Za kończące jego przebieg można uznać jedno ze zdarzeń: na przykład wnikanie plemnika przez osłonkę przejrzystą, kiedy jest już ustalone, jakim materiałem genetycznym będzie dysponować embrion, lub późniejszy moment zjednoczenia dwóch przedją-

\footnotetext{
${ }^{17}$ M. A. Warren, dz. cyt.

${ }^{18}$ Abstrahuję tu od ciężkich mutacji związanych z nieprawidłową liczbą chromosomów, jak w przypadku zespołu Downa, Klinefeltera czy Morgana, ponieważ chodzi tu o ogólną zasadę rozwoju płciowego.

${ }^{19}$ P. Singer, dz. cyt., s. 88-114.

${ }^{20}$ Z. Szawarski, Raport w sprawie statusu pozaustrojowej zygoty ludzkiej, „Seksuologia”, 1(19)1996.
} 
drzy, w wyniku którego powstaje unikalny genom nowego człowieka - jednak będzie to arbitralny wybór ${ }^{21}$.

Równie trafną krytykę można przeczytać u Tristama H. Engelhardta $\mathrm{w}$ jego The Ontology of Abortion ${ }^{22}$. Po pierwsze, materiał genetyczny zostaje po śmierci, kiedy dana osoba nie zamieszkuje już materialnego ciała. Po drugie, przyjęcie tego argumentu wiąże się z kolejnym paradoksem, który jest zauważany przez wielu innych bioetyków, między innymi Agatę Sagan i Petera Singera ${ }^{23}$. Technika polegająca na transferze jądra komórkowego z komórki somatycznej do enukleowanej (pozbawionej jądra komórkowego) komórki jajowej, prowadzi do wytworzenia klonu o genomie jądrowym identycznym z genomem dawcy jądra. Między oryginałem i klonem istnieje zatem ciągłość genetyczna, jednak nie są one tą samą osobą. Absurdem byłoby także utrzymywać, że każda komórka ciała, skoro jest potencjalnym klonem, jest osobą ludzką i ma prawo do życia ${ }^{24}$. Można by uciec od tego problemu, arbitralnie wykluczając tak powstałe klony z zakresu osób, jednak wtedy należałoby jednocześnie przekreślić przekonanie, że: „moje życie jako konkretnej osoby ludzkiej ma dla mnie tę samą wartość bez względu na sposób mojego poczęcia"25.

Inny wymiar argumentu z ciągłości organicznej daje analiza historyczna naszego gatunku. „Stworzenie duszy musi obejmować jednocześnie stworzenie tego oto ciała [...]. Dusza nie mogła być »wsadzona « w jakiekolwiek ciało, np. małpy. [...] Nie można uważać, że dusza została dodana do istniejącego już ciała zwierzęcego, posiadającego już jakąś inną formę substancjalną niż dusza" ${ }^{26}$. Według Howsepiana, mimo ciągłości organicznej i genetycz-

\footnotetext{
${ }^{21}$ Tamże, s. 6.

${ }^{22}$ H. T. Engelhardt Jr., The Ontology of Abortion, „Ethics” 1974, vol. 84, no. 3, s. 225.

${ }^{23}$ A. Sagan, P. Singer, The Moral Status of Stem Cells, „Metaphilosophy” 2007, vol. 38, no. 2-3, s. $264-284$.

${ }^{24}$ H. T. Engelhardt Jr., dz. cyt., s. 225; można argumentować, że wytworzony tą techniką klon będzie się różnił od oryginału genomem cytoplazmatycznym. Ale w przyszłości być może będzie możliwe wytworzenie klonu z cofniętej do fazy zygoty komórki somatycznej, a więc problem powraca.

${ }^{25}$ Z. Szawarski, Raport w sprawie statusu pozaustrojowej zygoty ludzkiej, „Seksuologia” 1996, 1 (19), s. 9.

${ }^{26}$ A. Świeżyński, Zagadnienie ewolucyjnej genezy duszy ludzkiej, [w:] Kontrowersje wokół początków człowieka, red. G. Bugajczyk, J. Tomczyk, Księgarnia św. Jacka Katowice 2007, s. 320.
} 
nej, między człowiekiem a innymi zwierzętami istnieje ogromna przepaść. To człowiek nosi obraz Boga i jest osobą ${ }^{27}$.

Rozważmy jednak taką myśl. Po porównaniu genomu człowieka z genomem szympansa, z którym jesteśmy najbliżej spokrewnieni, okazuje się, że około 500 genów w istotny sposób się różni ${ }^{28}$. Na podstawie starożytnego paradoksu soritesu ${ }^{29}$ można skonstruować następujący eksperyment myślowy: co by było, gdyby te 500 ludzkich genów sukcesywnie zastępować odpowiadającymi im genami szympansimi? Załóżmy, że poddajemy tej terapii szereg zygot, każdej następnej wprowadzając coraz więcej genów szympansich, a następnie pozwalamy im się rozwinąć. Powstaje pytanie, w którym momencie podstawimy o jeden gen za dużo i nastąpi rozwój istoty, którą nazwiemy szympansem, a nie człowiekiem. Taki eksperyment przypominałby przyspieszoną i odwróconą ewolucję. Tak jak ewolucja przebiega $\mathrm{z}$ wytworzeniem ogniw pośrednich, tak zapewne u transgenizowanych zygot obserwowalibyśmy wiele stanów pośrednich. Wprowadzenie granic określających, co jest człowiekiem, a co już nie, miałoby charakter czysto arbitralny ${ }^{30}$. Podobnie można zapytać o człowieczeństwo naszych przodków, australopiteków, pitekantropów i kromianiończyków. Ten eksperyment myślowy pozwala wątpić w to, czy człowieczeństwo rzeczywiście ma ostre granice.

\section{Zakończenie}

Człowiek nie jest czystą duchowością, ale posiada także ciało. W przypadkach granicznych, takich jak początek ludzkiego życia, biologizm człowieka jest wręcz zniewalający. Embrion nie śmieje się, nie wybiera, nie planuje.

\footnotetext{
27 A. A. Howsepian, Toward a General Theory of Person, „Christian Bioethics” 2000, vol. 6, no. 1, s. 15-35.

${ }^{28}$ P. P. Stępień, Ciagłość czy moment - rozważania genetyka, [w:] Kontrowersje wokół początków..., s. 23.

${ }^{29}$ Dotyczy on nieostrych pojęć, takich jak stos. Jeden kamień nie tworzy stosu i dwa kamienie też nie tworzą stosu; trzy kamienie nie tworzą stosu i cztery kamienie nie tworzą stosu, i tak dalej. Jednak w pewnym momencie okazuje się, że w ciągu listy tych przesłanek pojawia się zdanie: $n$ kamieni nie tworzy stos, ale $n+1$ kamieni tworzy stos. Trudno dokładnie określić wartość $\mathrm{n}$ z powodu rozmytych granic terminu 'stos'.

${ }^{30}$ P. P. Stępień, dz. cyt.
} 
Zasłona okrywająca wartość tego delikatnego życia jest tu najgrubsza, nie pozwala jasno określić, na ile można je cenić.

Otwierająca kontinuum życia biologicznego człowieka ludzka zygota wydaje się bezpieczną granicą ochrony życia, niepozwalającą na pogwałcenie praw ani jednej osoby. Spełnia swoją funkcję pod warunkiem, że nie ma osób poza naszym gatunkiem. W ogniu kontrargumentów stanowisko zwolenników tej granicy, opierających się na argumencie z ciągłości genetycznej, przestaje być oczywiste i wygodne.

\section{Bibliografia}

Bołoz W., Bioetyka i prawa człowieka, Wydawnictwo Uniwersytetu Kardynała Wyszyńskiego, Warszawa 2007, s. 221-241.

Engelhardt H. T. Jr., The Ontology of Abortion, „Ethics” 1974, vol. 84, no. 3, s. 217-234.

FitzPatrick W. J., Totipotency and the Moral Status of Embryos: New Problems for an old Argument, „Journal of Social Philosophy” 2004, vol. 35, no. 1, s. 108-122.

Ford N. M., Kiedy powstałem? Problem poczatku jednostki ludzkiej w historii w filozofii i w nauce, przeł. W. J. Popowski, PWN, Warszawa 1995, s. 140.

Howsepian A. A., Toward a General Theory of Person, „Christian Bioethics” 2000, vol. 6, no.1, s. 15-35.

Noonan J., An almost absolute value in history, cyt. za: M. A. Warren, The moral status of the gene, [w:] A Companion to Genetics, eds. J. Burley, J. Harris, Blackwell Publishing 2004.

Rovane C., Genetics and Personal Identity, [w:] A Companion to Genetics, eds. J. Burley, J. Harris, Blackwell Publishing 2004, s. 245-252.

A. Sagan, P. Singer, The Moral Status of Stem Cells, „Metaphilosophy” 2007, vol. 38, no. $2-3$, s. 264-284.

Sak J., Kiciński P., Kołodziejczyk B., Marczewski K., Bioetyczne aspekty ochrony życia człowieka w okresie prenatalnym, [w:] Etyka wobec sytuacji granicznych, red. D. Probucka, Oficyna Wydawnicza „Impuls”, Kraków 2007, s. 182.

Singer P., O życiu $i$ śmierci. Upadek etyki tradycyjnej, przel. A. Alichniewicz i A. Szczesna, Państwowy Instytut Wydawniczy, Warszawa 1997, s. 88-114.

Steinbock B., Preimplantation Genetic Diagnosis and Embryo Selection, [w:] A Companion to Genetics, eds. J. Burley, J. Harris, Blackwell Publishing 2004.

Stępień P. P., Ciagłość czy moment - rozważania genetyka, [w:] Kontrowersje wokót poczatków człowieka, red. G. Bugajczyk, J. Tomczyk, Księgarnia św. Jacka, Katowice 2007. 
Szawarski Z., Etyka i przerywanie ciąży, [w:] W kręgu życia i śmierci. Moralne problemy medycyny współczesnej, red. Z. Szawarski, Książka i Wiedza, Warszawa 1987, s. $169-201$.

Szawarski Z., Raport w sprawie statusu pozaustrojowej zygoty ludzkiej, „Seksuologia” 1996, 1 (19).

Świeżyński A., Zagadnienie ewolucyjnej genezy duszy ludzkiej, [w:] Kontrowersje wokót początków człowieka, red. G. Bugajczyk, J. Tomczyk, Księgarnia św. Jacka, Katowice 2007, s. 311-323.

Warren M. A., The moral status of the gene, [w:] A Companion to Genetics, eds. J. Burley, J. Harris, Blackwell Publishing 2004.

\begin{abstract}
Genetics of Humanity. Criticism of the Argument of Genetic Continuum

Determination of the moral status of the human embryo involves finding a rigid measure of human value - a reference system which would allow us to make unambiguous moral choices and laws. At the very beginning, supporters of the conception criterion of humanity (immediate animation) must substantiate the grounds on which human moral status is constant despite the obvious quantitative and qualitative changes of the body during development. For this purpose, it must be demonstrated that the embryo and the adult man that developed from it are substantially the same being ${ }^{1}$. The purpose of this article is to review the exchange of ideas on one of the most important and most graceful arguments for humanity from fertilization - the argument of genetic continuum. The argumentation of its followers bases on the fact that at the moment of fertilization, when a human ovum fuses with a human sperm, an unique set of genes is formed that does not change during the further growth and development. The criticism of this position is to point to three problems: the genetic identity of identical twins, genetic determinism and blur border designated in this way.
\end{abstract}

Keywords: ethics, embryo, humanity, genetic continuum, immediate animation 